\title{
Allometric Equations for Estimating Silk Oak (Grevillea robusta) Biomass in Agricultural Landscapes of Maragua Subcounty, Kenya
}

\author{
Omamo Augustine Owate $\mathbb{D}^{1},{ }^{1}$ Mugo Joseph Mware, ${ }^{2}$ and Mwangi James Kinyanjui ${ }^{2}$ \\ ${ }^{1}$ Kenya Forest Service, P.O. Box 30513-00100, Nairobi, Kenya \\ ${ }^{2}$ School of Natural Resources, Karatina University, P.O. Box 1957, Karatina, Kenya \\ Correspondence should be addressed to Omamo Augustine Owate; augustineowate@yahoo.com
}

Received 23 April 2018; Revised 8 August 2018; Accepted 16 August 2018; Published 2 October 2018

Academic Editor: Scott D. Roberts

Copyright (C) 2018 Omamo Augustine Owate et al. This is an open access article distributed under the Creative Commons Attribution License, which permits unrestricted use, distribution, and reproduction in any medium, provided the original work is properly cited.

\begin{abstract}
Grevillea robusta is widely interplanted with crops in Maragua subcounty, a practice that enhances biomass quantities in farmlands. However, quick tools for estimating biomass of such trees are lacking resulting in undervaluation of the farm product. This study sought to develop allometric equations for estimating tree biomass using diameter at breast height (DBH) and tree height as predictor variables. Tree biomass was computed using thirty-three (33) trees randomly selected from 12 one hectare plots established in each of the four agroecological zones (AEZs). DBH of all Grevillea robusta trees per plot was measured and three trees were selected for destructive sampling to cover the variety of tree sizes. Regression analysis was used to develop equations relating $\mathrm{DBH} /$ tree height to biomass based on linear, exponential, power, and polynomial functions. The polynomial and the power equations had the highest $\mathrm{R}^{2}$, lowest SEE, and MRE values, while DBH was the most suitable parameter for estimating tree biomass. The tree stem, branches, foliage, and roots biomass comprised $56.89 \%, 14.11 \%, 6.67 \%$, and $22.32 \%$ of the total tree biomass, respectively. The mean tree biomass density $\left(12.430 \pm 1.84\right.$ ton $^{-1}$ ) showed no significant difference $(\mathrm{p}=0.09)$ across AEZs implying no difference in G. robusta agroforestry stocks across the AEZ. The allometric equations will support marketing of tree products by farmers and therefore better conservation and management of the tree resource.
\end{abstract}

\section{Introduction}

Trees in agricultural ecosystems offset pressure on forest resources in conventional forests and therefore play a major role in sustaining the productivity of agricultural and forested landscapes. They are a source of livelihood for the rural communities providing wood and nonwood products like resin, honey, medicine, vegetables, among others and are also important in conservation of biological diversity, water, and soil conservation [1]. They represent a vital source of food for many of the world's poorest people, providing both stable and supplemental foods, fodder and fuel for lighting, and cooking and food processing. Besides, they are also important in biological diversity conservation and mitigating climate change through carbon sequestration [2].
Quantification of the amount of biomass and/or carbon stored in trees presently is an important component in the implementation of the emerging carbon credit such as Reducing Emissions from Deforestation and Degradation $\left(\mathrm{REDD}^{+}\right)$[3]. Developing countries including Kenya can benefit from $\mathrm{REDD}^{+}$related mechanisms by providing accurate information about their forest and tree resources. REDD+ requires countries to establish measurement, reporting, and verification (MRV) methods [4]. This may consists of inventory of forests/trees in sampled plots and application of appropriate allometric equations to estimate biomass [2]. Biomass estimates eventually are converted into carbon and carbon dioxide $\left(\mathrm{CO}_{2}\right)$ equivalents.

Most of the small scale farmers in Maragua integrate trees (mainly Grevillea robusta) with crops in their farms. 
The specific economic values of the trees planted in agricultural landscapes have not been fully explored. Since no marketing guidelines have been developed for the different tree products, prices of the products are normally determined by agreements between the seller and the buyer, and this varies from area to another, size of tree or product, and the targeted use of the product. In many cases, such negotiations do not favor the farmer and lowers the value of the tree, thus demotivating farmers from planting trees. A method that helps establish biomass stocks and provides accurate information about the available wood resources from this species would help in its management and conservation and would enhance the livelihoods of the farmers.

Some allometric equations have been developed to estimate tree biomass quantities using easily measurable parameters such as DBH and height [1-3]. Henry et al. [1] and Kuya et al. [5] constructed equations for estimating tree biomass in agricultural landscapes of western Kenya while Kinyanjui et al. [6] constructed an equation for inventory of the above ground biomass in the Mau Forest Ecosystem of Kenya. Mugo et al. [7] predicted stem diameter of open grown trees in western Kenya. Since tree allometry varies from site to site [8], such equations may not be appropriate for the conditions of Maragua subcounty in terms of agro ecological zonation and the purpose for which the trees are grown. Here, a variety of wood products are marketed for various uses including timber, firewood, pole wood, and fencing and some leaves have been used as livestock fodder. Hence, to meet the study area specific needs for tree products and tree components, it was necessary that equations for estimating G. robusta biomass quantities in the farming landscapes of Maragua subcounty are developed.

The purpose of this study was to develop equations relating tree biomass with easily measurable parameters of diameter at breast height (DBH) and height as a quick tool for valuation of tree products. The study also sought to assess variations of $G$. robusta biomass among agroecological zones of the study area as a basis for developing tree resource management plans.

\section{Materials and Methods}

2.1. Study Area. The study was done in Maragua subcounty of Murang'a county in central Kenya (Figure 1). The area covers $839 \mathrm{Km}^{2}$ [9], between longitude $36^{\circ} 30^{\prime} \mathrm{E}$ and $37^{\circ} 30^{\prime} \mathrm{E}$ and latitude $00^{\circ} 30^{\prime} \mathrm{S}$ and $1^{\circ} \mathrm{S}$. The study area consists of four upper midland agroecological zones (AEZ) as illustrated in Table 1. Such variations of altitude and climate are expected to influence allometry and also biomass productivity of $G$. robusta trees.

2.2. Physical and Topographic Features. The study area is a major source of numerous springs and rivers that drain into River Tana through rivers Maragua, Irati, Sabasaba, Kabuku, Makindi, Thuki, Thamuru, and Thika [9]. The geology of the subcounty consists of volcanic rocks of the Pleistocene age and basement system rock of Achaean type. Volcanic rocks occupy the western part of the county bordering the Aberdare ranges while rocks of the basement system are in the eastern part. Porous beds and disconformities within the volcanic rock system form important aquifers, collecting, and moving ground water, thus regulating water supply from wells and boreholes. In the study area Jaetzold et al. [10] classified and described soils in AEZ as shown in Table 2.

2.3. Land Use Activities. Farmers in the study area have actively adopted agroforestry [11]. Land use systems range from subsistence small holder farms to more cash crop oriented farms which relatively range from 1.5 to 2 acres. Woody vegetation forms part of the agricultural landscape which varies from single tree to small stands that consists of mainly exotic trees and isolated indigenous trees managed in different ways [11]. Trees are grown around the homesteads, in woodlots and croplands, and along farm boundaries. Githiomi et al. [11] further stated that trees and shrubs are grown around the homestead, in woodlots and cropland, and along farm boundaries and that woodlots are in small mono specific clusters of trees mainly in lower areas of the study area. According to Kuya et al. [5], such land use activities influence the biomass of agricultural landscapes in different ways depending on management activities.

2.4. Sampling Design. Stratified systematic sampling was used on a Geographical Information System (GIS) platform to select sampling sites in each of the AEZs. Each AEZ was divided into three equal polygons and the centre of each polygon was used as the reference data collection point (Figure 2). The position of the data collection point identified on the GIS map was recorded (Table 3), transferred into a GPS, and traced to the ground. The GPS readings were based on the UTM/UPS format in UTM zone 37S. A one hectare $(100 \times 100 \mathrm{~m})$ plot was established at the reference point aligned to the North-South and East-West grids. All the G. robusta trees in the plot were recorded for diameter at 1.3 from the ground (DBH) and total height. Three G. robusta trees in each plot were selected for destructive sampling based on a proportional allocation among size classes identified in the plot.

\subsection{Processing of Destructively Sampled Trees}

2.5.1. Destructive Sampling. All the G. robusta trees selected for destructive sampling were categorized into DBH classes. The selected trees were uprooted onto tarpaulin sheets spread on felling direction (to avoid loss of foliage), leaves stripped off and debranched, and total tree length/height (HT) measured using a linear tape. Each of the trees was then divided into components (trunk, branches, foliage, and roots) and the trunk was cross cut to manageable sizes. The tree components were weighed in the field and their fresh weight was recorded. Samples were taken from the different components of the tree and their fresh weight was taken. The samples were subsequently oven-dried in the laboratory at $105^{\circ} \mathrm{C}$ as guided by [12].

Similarly the branches were trimmed, cross cut, and classified into four diameter classes as $0<\mathrm{D}<2 \mathrm{~cm}$ (Class 


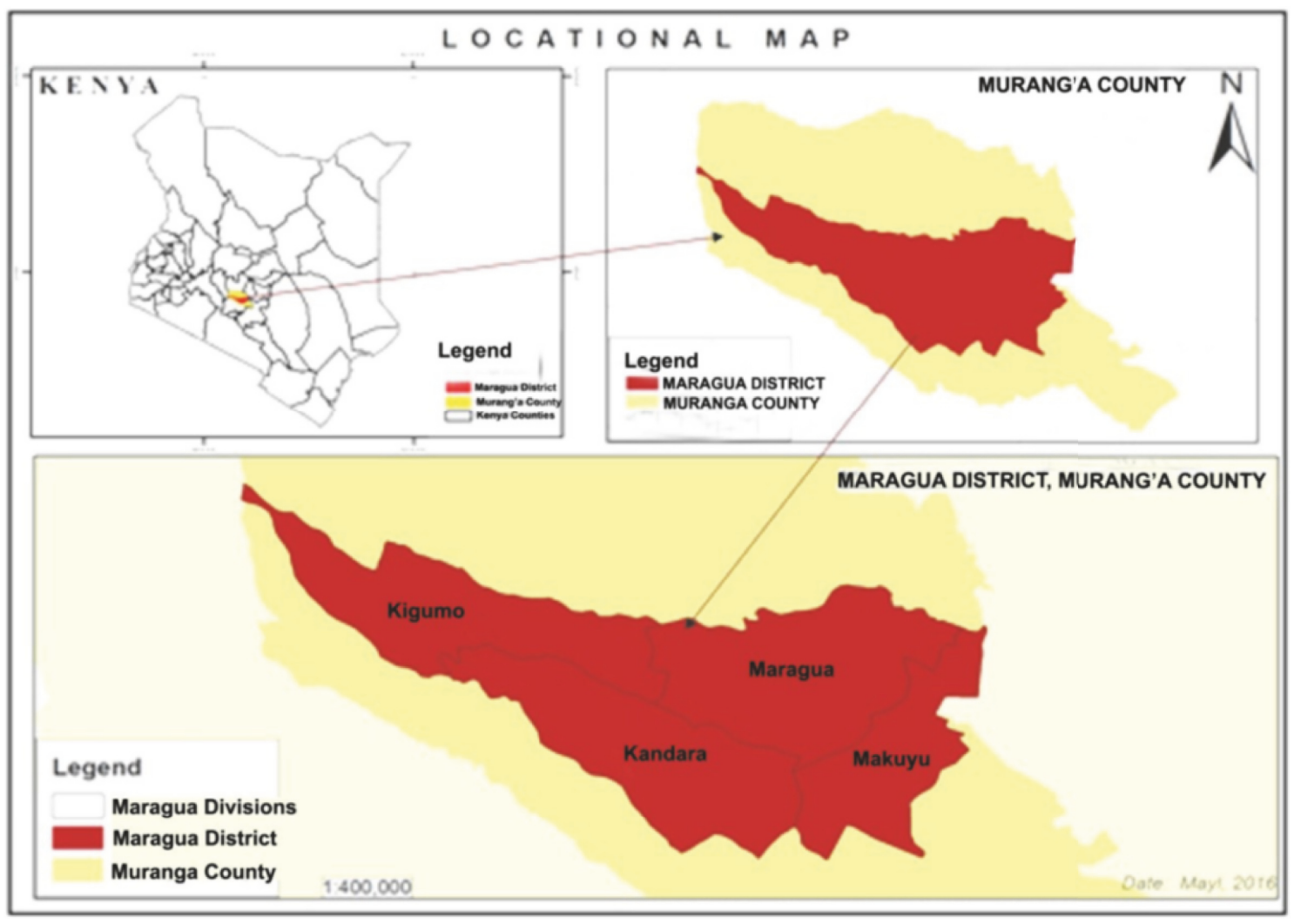

FIGURE 1: Study area. Showing the location on Kenyan map and within the Murang'a county.

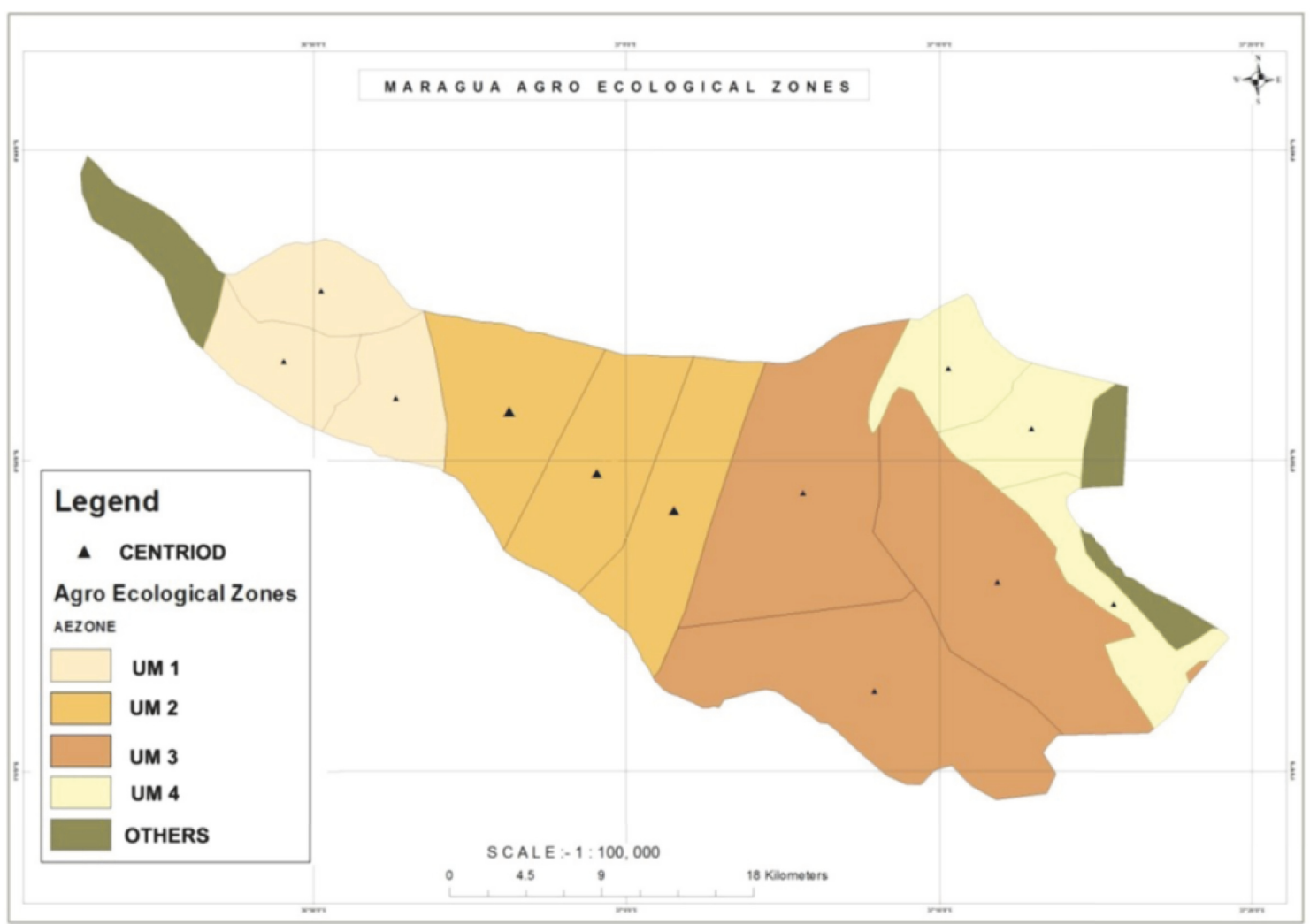

FIgURE 2: Maragua agroecological zones, showing polygons per zone and points for data collection. 
TABLE 1: Biophysical and climatic conditions of Maragua subcounty (source [10]).

\begin{tabular}{lcccc}
\hline Attribute & Upper midland 1 (UM 1) & Upper midland 2 (UM 2) & Upper midland 3 (UM 3) & Upper midland 4 (UM 4) \\
\hline Altitude range $(\mathrm{m})$ & $1730-2430$ & $1500-1730$ & $1340-1500$ & $1060-1340$ \\
Mean annual Rainfall $(\mathrm{mm})$ & 2200 & 1537.5 & 955 & 970 \\
Mean annual Temperature $\left({ }^{\circ} \mathrm{C}\right)$ & $18.4^{\circ} \mathrm{C}$ & $19.3^{\circ} \mathrm{C}$ & 20.2 & 21.2 \\
\hline
\end{tabular}

TABLE 2: Classification and description of soil in Maragua subcounty.

\begin{tabular}{|c|c|c|}
\hline AEZ & Physiographic Lithology & Soil description \\
\hline UM 1 & MV2 & $\begin{array}{l}\text { Well drained, very deep, dark reddish to dark brown, very friable and smeary, clay loam } \\
\text { to clay, with thick acid humic topsoil, in places shallow to moderately deep and rocky: } \\
\text { Humic ANDOSOLS, partly lithic phase }\end{array}$ \\
\hline \multirow[t]{2}{*}{ UM 2} & $\mathrm{RB} 1$ & $\begin{array}{l}\text { Well drained, extremely deep, dark reddish brown to dark brown, friable and slightly } \\
\text { smeary clay with an acid humic topsoil: Ando-humic NITISOLS: with humic } \\
\text { ANDOSOLS. }\end{array}$ \\
\hline & $\mathrm{RB} 2$ & $\begin{array}{l}\text { well drained, extremely deep, dusky red to dark reddish brown, friable clay with an acid } \\
\text { humic topsoil: humic NITISOL }\end{array}$ \\
\hline UM 3 & RB3 & $\begin{array}{l}\text { Well drained, extremely deep, dusky red to dark reddish brown friable clay; with inclusion } \\
\text { of well drained, moderately deep, dark red to dark reddish brown, friable clay over rock, } \\
\text { pisoferric or petroferric materials. Eutric NITISOLS: with nito-chromic CAMBISOLS } \\
\text { and chromic ACRISOLS and LUVISOLS, partly lithic, pisoferric or petroferric phase }\end{array}$ \\
\hline UM 4 & LB1 & Well drained, very deep, dark red, very friable clay: Nito-rhodic FERRALSOLS. \\
\hline
\end{tabular}

TABLE 3: Coordinates of data collection points for all the AEZs.

\begin{tabular}{lccc}
\hline Agroecological Zone & Plot number & Eastings $(\mathrm{m})$ & Nothings $(\mathrm{m})$ \\
\hline \multirow{3}{*}{ UM 4 } & 1 & 305449.791 & 9900308.287 \\
& 2 & 301575.475 & 9908749.165 \\
& 3 & 297040.133 & 9914658.828 \\
\hline \multirow{2}{*}{ UM 3 } & 1 & 290497.054 & 9896663.132 \\
& 2 & 298551.514 & 9903069.450 \\
& 3 & 289507.887 & 9901526.723 \\
\multirow{2}{*}{ UM 2 } & 1 & 281419.488 & 9909982.717 \\
& 2 & 276445.967 & 9904576.637 \\
& 3 & 268721.854 & 9911103.375 \\
\hline \multirow{3}{*}{ UM 1 } & 1 & 263165.408 & 9896663.132 \\
& 2 & 259196.650 & 9918509.281 \\
& 3 & 256504.015 & 9914786.820 \\
\hline
\end{tabular}

1), $2 \leq \mathrm{D}<5 \mathrm{~cm}$ (Class 11), $5 \leq \mathrm{D}<10 \mathrm{~cm}$ (Class 111), and $\mathrm{D} \geq 10 \mathrm{~cm}$ (Class IV) for easy of weighing. Their weights were taken for green weight to the nearest $0.1 \mathrm{~kg}$. The heavier ones were measured as individual billets while the lighter ones were bundled together and weighed for their green weight. Aliquots were taken and labeled and their green weight was recorded to the nearest $0.01 \mathrm{gm}$ kept in bags and taken to the laboratory for oven-dry $\left(105^{\circ} \mathrm{C}\right)$ weight measurement. The foliage was collected on to the tarpaulin sheet, bundled into gunny bags whose weights were known, and weighed to the nearest $0.1 \mathrm{~kg}$. Their green weights were calculated as the difference between the gross weight and the weight of the empty gunny bags and recorded. A sample of the foliage was taken from the combined mass of the foliage, weighed, recorded to the nearest $0.01 \mathrm{gm}$, and oven-dried $\left(70^{\circ} \mathrm{C}\right)$.
Excavation of the tree was done manually until all the roots were removed. The taproot was followed to its endpoint and root length recorded. Soil embedded in the stump joints and on root surface was removed by use of a brush and water. The roots were classified into size classes as (Class 1) $0<\mathrm{D}<$ $2 \mathrm{~cm}$, (Class 11) $2 \leq \mathrm{D}<10 \mathrm{~cm}$, and (Class 111) $\mathrm{D} \geq 10 \mathrm{~cm}$ for ease of weighing. Roots were weighed by size classes for green weight and recorded. An aliquot of each root size class was extracted and weighed for green weight, recorded, tagged, packaged, and taken to the laboratory to oven-dry at $105^{\circ} \mathrm{C}$. In all the cases, the aliquots were left in the oven to dry and changes in dry weight were monitored on a daily basis until they reached a constant weight.

2.5.2. Biomass Measurement. The aliquot's green and ovendry weights were used to get the dry-green weight ratios. These were subsequently used to convert the green weight of the tree component (trunks, branches, foliage, or roots) to dry weight, which is the component's biomass. The total aboveground (AGB) biomass was obtained by getting the sum of the biomass of the trunk, branches, and foliage. Similarly the total belowground (BGB) biomass was obtained by summing up all the dry weights of all the root sections of that given tree. Finally the total tree biomass (TTB) was obtained by adding up aboveground and belowground biomass. Scatter plots and function graphs were used in assessing the relationships between easily measurable variables of DBH and HT together with a combination of $\mathrm{DBH}$ and $\mathrm{HT}$ against total tree biomass and tree component biomass

2.5.3. Development of Biomass Equations. Thirty-three destructively sampled trees were used to develop the biomass estimation allometric equations. The measured predictor 
TABLE 4: Biomass partitions (Kg) of each component and total tree biomass of sampled trees for every AEZ.

\begin{tabular}{lcccccc}
\hline Zone & Stem & Branches & Foliage & AGB & BGB & TTB \\
\hline UM 1 & 550.25 & 129.84 & 81.05 & 761.14 & 166.83 & 327.95 \\
UM 2 & $1,011.10$ & 218.45 & 87.36 & $1,316.91$ & $1,689.47$ \\
UM 3 & $1,204.43$ & 332.89 & 145.24 & $1,682.56$ & 535.24 & $2,217.84$ \\
UM 4 & 838.14 & 213.13 & 109.07 & $4,160.84$ & 339.87 & $1,500.61$ \\
\hline Total & $3,604.32$ & 894.31 & 422.72 & $4,925.45$ & $1,414.50$ \\
\hline
\end{tabular}

TABLE 5: Percentage contribution to total tree biomass among tree components in the different AEZ.

\begin{tabular}{lccccc}
\hline Zone & Stem & Branches & Foliage & AGB & BGB \\
\hline UM 1 & 59.30 & 13.99 & 8.73 & 82.02 & 77.95 \\
UM 2 & 59.85 & 12.93 & 5.17 & 75.86 & 22.05 \\
UM 3 & 54.31 & 15.01 & 6.55 & 77.36 & 24.13 \\
UM 4 & 55.85 & 14.20 & 7.27 & 22.65 \\
\hline Total & 56.89 & 14.11 & 6.67 & 77.74 \\
\hline
\end{tabular}

variables $\mathrm{DBH}$, height $(\mathrm{Ht})$, and product of $\mathrm{DBH}$ and $\mathrm{HT}$ $(\mathrm{DBH} * \mathrm{Ht})$ for each of the destructively sampled trees were regressed to the dry weight (biomass) of the total tree biomass (TTB) or component biomass [(AGB), (BGB) branches biomass (BR), and foliage biomass $(\mathrm{F})]$.

Scatter plots were used in illustrating the relationships between total tree and tree component biomass with the easily measurable variables. To derive the equation for each of the dependent variable (TTB, AGB, BGB, BR, and F) the regression functions (exponential, linear, polynomial, and power) were superimposed on the scatter plot graphs. The selection of the best fit equation was based on the lowest standard error of the estimate (SEE) which is the standard deviation of the residuals: the lowest residual mean error (RME) and the highest coefficient of determination $\left(\mathrm{R}^{2}\right)$.

2.5.4. Validation of Developed Allometric Equations. The mean differences between predicted and observed biomass were used to test the suitability of the equation. Simple linear regression analysis between observed and predicted values of the equations quantifies the tendency of residuals whereby $\mathrm{R}^{2}$ and mean standard error (MSE) indicate the precision of the estimates. Residual plots were also used to assist in the evaluation of the equations. Bias\% was computed as ((predicted biomass-measured biomass)/measured biomass) $* 100$ [13].

Finally the developed equation for total tree biomass was compared with several equations in similar management units but different geographical areas. The two sets of biomass values were subjected to a paired $t$ test [14] to find if differences occur in each biomass estimate comparison.

\section{Results}

3.1. Preliminary Findings of the Dataset. A total of 1,090 trees were measured for DBH in the twelve (12) plots 222 in AEZ 1, 308 in AEZ2, 292 in AEZ 3, and 268 in AEZ 4. The values for $\mathrm{DBH}$ ranged from $1 \mathrm{~cm}$ to $39.5 \mathrm{~cm}$ with a mean of $11.08 \mathrm{~cm}$ in $\mathrm{AEZ1}, 11.51 \mathrm{~cm}$ in AEZ 2, $10.07 \mathrm{~cm}$ in AEZ 2, and $12.14 \mathrm{~cm}$ in
AEZ 4. Height values ranged from $6.0 \mathrm{~m}$ to $24.8 \mathrm{~m}$ with a mean of $11.67 \mathrm{~m}$ in AEZ 4, 13.32m in AEZ 3, 14.03m in AEZ 2, and $11.42 \mathrm{~m}$ in AEZ 1. Out of the 1090 trees measured for DBH, 33 trees were destructively sampled for biomass measurements.

3.2. Percentage Contributions of Different Tree Components Biomass. The summary distribution of the total tree biomass and tree biomass components of the thirty-three destructively sampled trees of different sizes recorded in the study area are as shown in Tables 4 and 5. The total tree biomass (TTB) for the 33 trees was $6,335.89 \mathrm{~kg}$ distributed as follows: stem/trunk (56.89\%), branches (14.11\%), foliage (6.67\%), and roots $(22.33 \%)$. Thus aboveground biomass (AGB) comprised $77.74 \%$ while belowground biomass (BGB) was $22.33 \%$. These are the proportions of biomass available for specific uses, e.g., timber (stem biomass), fuel wood (branches biomass), mulch/livestock feed/green manure (foliage biomass), and soil organic carbon services (roots).

The stem comprises the largest percentage of the total tree biomass (Table 5) while foliage has the least biomass contribution and this is in agreement with similar studies $[1,5,15]$. The $22.33 \%$ proportion of BGB is close to the IPCC default value for BGB which is taken as $24 \%$ [16]. The slight variations in allocation among AEZ could be a justification for development of very specific allometric equations for each of the AEZ. For example, the results indicated a slight increase in $\mathrm{BGB} / \mathrm{AGB}$ ratio with altitude rise from UM1 (0.219) to UM4 (0.293). Such information on component ratios among G. robusta and which is based on tree allometry variations requires further research and supports its conservation and usage.

3.3. Illustrations of Biomass Estimation from Various Functions. Various functions were plotted and the biomass estimates done for each function. The goodness of fit in each regression was illustrated by the coefficient of determination $\left(\mathrm{R}^{2}\right.$ value) which explains how close the measured data are to 
TABLE 6: Allometric equations for estimating various biomass using DBH.

\begin{tabular}{|c|c|c|c|c|}
\hline Function & Equations & MRE & $\mathrm{R}^{2}$ & SEE \\
\hline Exponential & $T T B=10.91 e^{0.150 D B H}$ & -29.10 & 0.84 & 4.57 \\
\hline Power & $T T B=1.811 D B H^{1.658}$ & 5.05 & 0.98 & 1.34 \\
\hline Polynomial & $T T B=0.322 D B B H^{2}+7.93 D B H-19.26$ & 0.15 & 0.93 & 1.33 \\
\hline Linear & $T T B=18.00 D B H-73.22$ & 0.07 & 0.91 & 1.52 \\
\hline Multiple & $T T B=11.356 \mathrm{DBH}-8.924 \mathrm{HT}+0.536(\mathrm{DBH} * H T)+18.27$ & -0.16 & 0.93 & 1.40 \\
\hline Exponential & $A G B=8.474 e^{0.150 D B H}$ & -22.60 & 0.83 & 3.56 \\
\hline Power & $A G B=1.384 D B H^{1.665}$ & 3.2 & 0.98 & 0.99 \\
\hline Linear & $A G B=13.99 D B H-56.96$ & 0.02 & 0.92 & 1.12 \\
\hline Polynomial & $A G B=0.248 D B H^{2}+6.243 D B H-15.45$ & 0.002 & 0.94 & 0.99 \\
\hline Multiple & $A G B=8.641 D B H-6.9 H T+0.424(D B H * H T)+14.53$ & 0.06 & 0.90 & 1.98 \\
\hline Exponential & $B G B=2.311 e^{0151 D B H}$ & -5.13 & 0.82 & 1.04 \\
\hline Polynomial & $B G B=0.074 D B H^{2}+1.688 D B H-3.791$ & 0.10 & 0.82 & 0.50 \\
\hline Linear & $B G B=4.013 D B H-16.24$ & -0.01 & 0.81 & 0.53 \\
\hline Multiple & $B G B=2.713 D B H-2.028 H T+0.111(D B H * H T)+3.79$ & 0.10 & 0.82 & 0.51 \\
\hline Power & $B G B=0.401 D B H^{1.642}$ & 3.42 & 0.93 & 0.51 \\
\hline
\end{tabular}

the fitted regression line [14]. These illustrations are shown in Figures 3, 4, and 5.

A comparison of functions for estimating TTB from DBH illustrates that the exponential function overestimates $\mathrm{DBH}$ for a tree of $35 \mathrm{~cm} \mathrm{DBH}$. Though the other three functions have a near similar estimate, the $\mathrm{R}^{2}$ values favor the power function $\left(R^{2}=0.97\right)$ and the polynomial function $\left(R^{2}=0.93\right)$. Though the linear function gives relatives good $\mathrm{R}^{2}$ value, foresters have disqualified linear relationships because they do not illustrate the ideal relationship between predictor variables and biomass or volume over a wide diameter size distribution $[8,16]$.

Estimation of total tree biomass from height varied greatly among functions making it difficult to select the ideal function. The $\mathrm{R}^{2}$ values were also lower compared to those of using $\mathrm{DBH}$ as a predictor variable. The same trend was noted in estimating ABG from tree height. Noting that height measurement in forests is difficult and the fact that farmers sell trees while standing, the use of tree height may increase tree biomass or volume estimation costs, while not increasing accuracy of estimates. As such trials of height as a biomasspredictor variable were discarded in favor of $\mathrm{DBH}$ which is easy to measure and can be measured with high levels of accuracy $[6,8]$.

$\mathrm{DBH}$ gives a good estimate of AGB based on $\mathrm{R}^{2}$ values with 0.98 for the power function and 0.94 for the polynomial function. Kuya [5] identified power functions as most ideal for estimating AGB in western Kenya while Henry et al. [1] preferred polynomial functions. It has been found that either of these functions is ideal based on the diameter size distribution [8]. Kuya [5] preferred power functions because of the large DBH size distribution which disqualifies polynomial functions which often have two turning points [14] and may not define the biomass-predictor relationship over a wide range of diameter sizes. In this case where $G$. robusta does not grow to large sizes in the study area, either a polynomial or a power function becomes ideal based on this criteria of choice.

3.4. Choice of Equation Based on Standard Error of Estimate and Mean Residual Error. Apart from the coefficient of determination, the standard error of estimate (SEE) and the mean residual error (MRE) have been used in choice of appropriate regression equations [14]. The SEE is a measure of the accuracy of predictions made with a regression line and the lower the value, the better the accuracy of an allometric equation [8]. Zar [14] also explains the mean residual error as another measure of the accuracy of a regression equation. Since residuals are differences between the data points and the regression line, the mean residual error refers to the error that is not explained by the regression line.

The choice of equation based on the three statistics is illustrated for the various biomass components in Table 6

Though linear functions had the least MRE for TTB and $\mathrm{BGB}$, their previously described limitations $[8,14]$ disqualifies them. The polynomial functions have very small MRE values in all estimated biomass components of TTB $(0.15 \mathrm{~kg})$, AGB $(0.002 \mathrm{Kg})$, and BGB $(0.1 \mathrm{Kg})$ illustrating their appropriateness based on this second selection criteria. Exponential functions have large mean bias in all functions and this further illustrates their inappropriateness in this selection. A bias of less than $5 \%$ of the total tree biomass is within acceptable range $[16,17]$ and would provide the farmers with the real value of the tree. In this case the polynomial function is very accurate with very minimal bias within the range of diameter sizes tested.

Based on the SEE, the polynomial function gave the lowest values at 1.33 for TTB, 0.99 for $\mathrm{ABG}$, and 0.5 for $\mathrm{BGB}$. This compared well with the power function which had 1.34 for TTB, 0.99 for AGB, and 0.51 for BGB. In this third selection criteria, the polynomial function again takes best preference. 

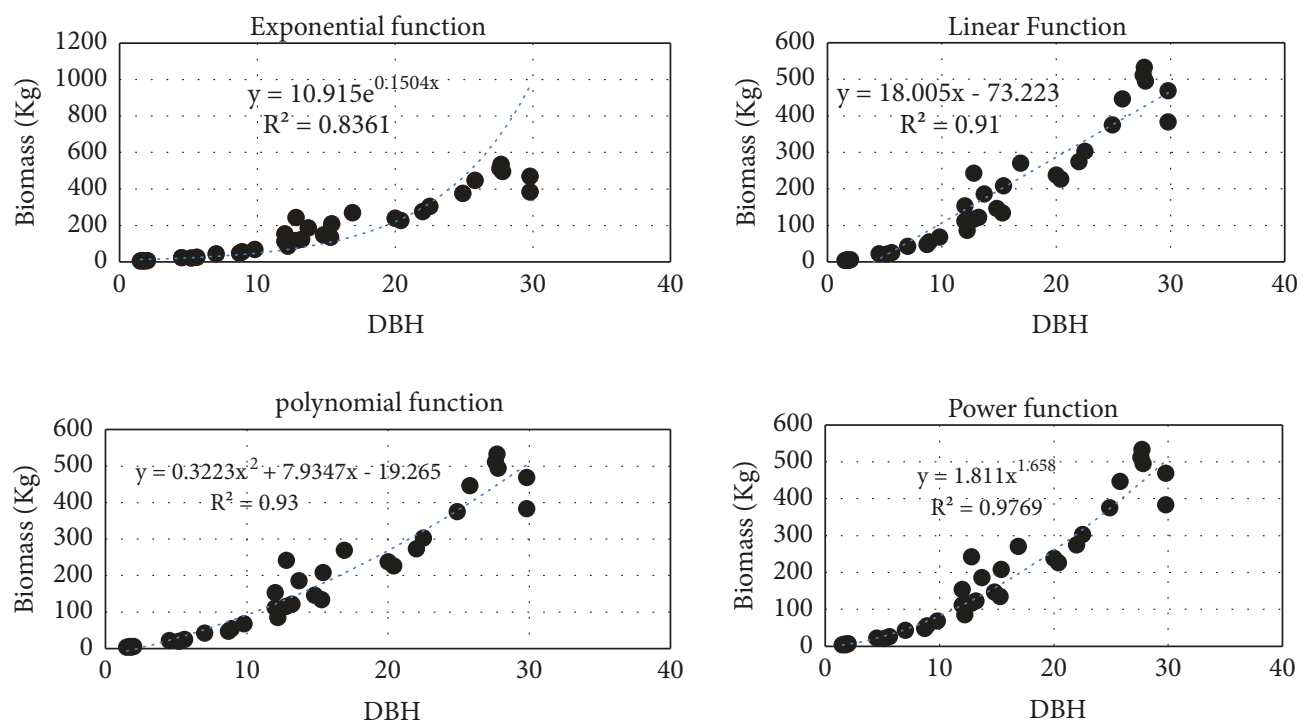

FIGURE 3: Comparison of functions for estimating total tree biomass from DBH.
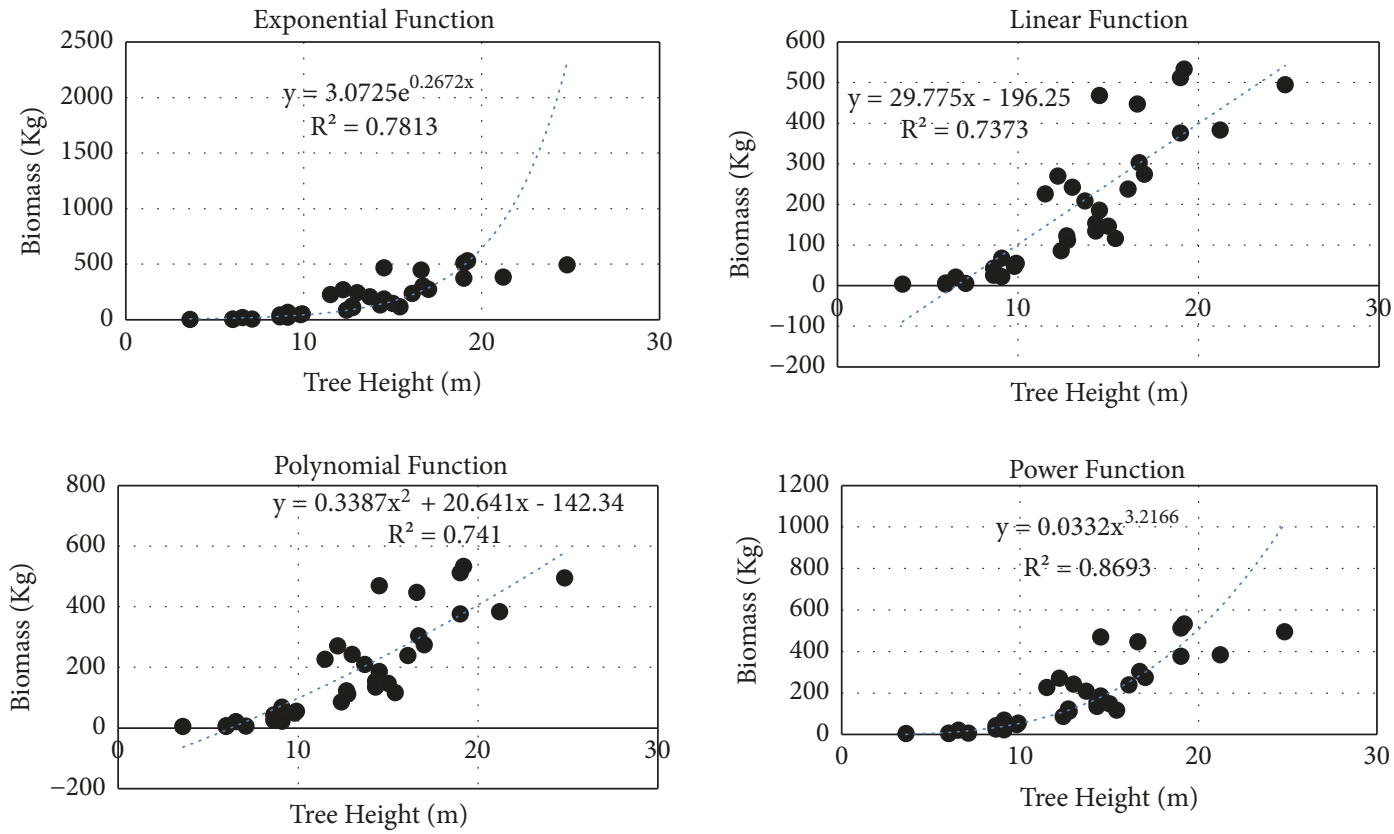

FIGURE 4: A comparison of functions for estimating total tree biomass from tree height.

Based on the statistics, Table 7 shows the list of preferred equations for estimating the different tree biomass components. Though all the preferred equations are polynomial functions, it should be noted that the power functions were the next best alternative and their application has already been illustrated for agroforestry species of western Kenya [5]. The limitation of two turning points observed in polynomial functions [14] may not apply in the study area where $G$ robusta grows because the trees do not grow beyond the $40 \mathrm{~cm} \mathrm{DBH}$ size that was used in this study. It is however recommended that such equations should not be applied where trees of bigger sizes grow.
TABLE 7: A list of selected allometric equations for estimating biomass components.

\begin{tabular}{lc}
\hline Biomass component & Equations \\
\hline Total Tree & $T T B=0.322 D B B H^{2}+7.93 D B H-19.26$ \\
\hline Above ground & $A G B=0.248 \mathrm{DBH}^{2}+6.243 \mathrm{DBH}-15.45$ \\
\hline Below ground & $B G B=0.074 \mathrm{DBH}^{2}+1.688 \mathrm{DBH}-3.791$ \\
\hline Branches & $\mathrm{BRA}=0.030 \mathrm{DBH}^{2}+1.574 \mathrm{DBH}-4.984$ \\
\hline Foliage & $\mathrm{F}=0.04 \mathrm{DBH}^{2}+1.949 \mathrm{DBH}-3.134$ \\
\hline
\end{tabular}



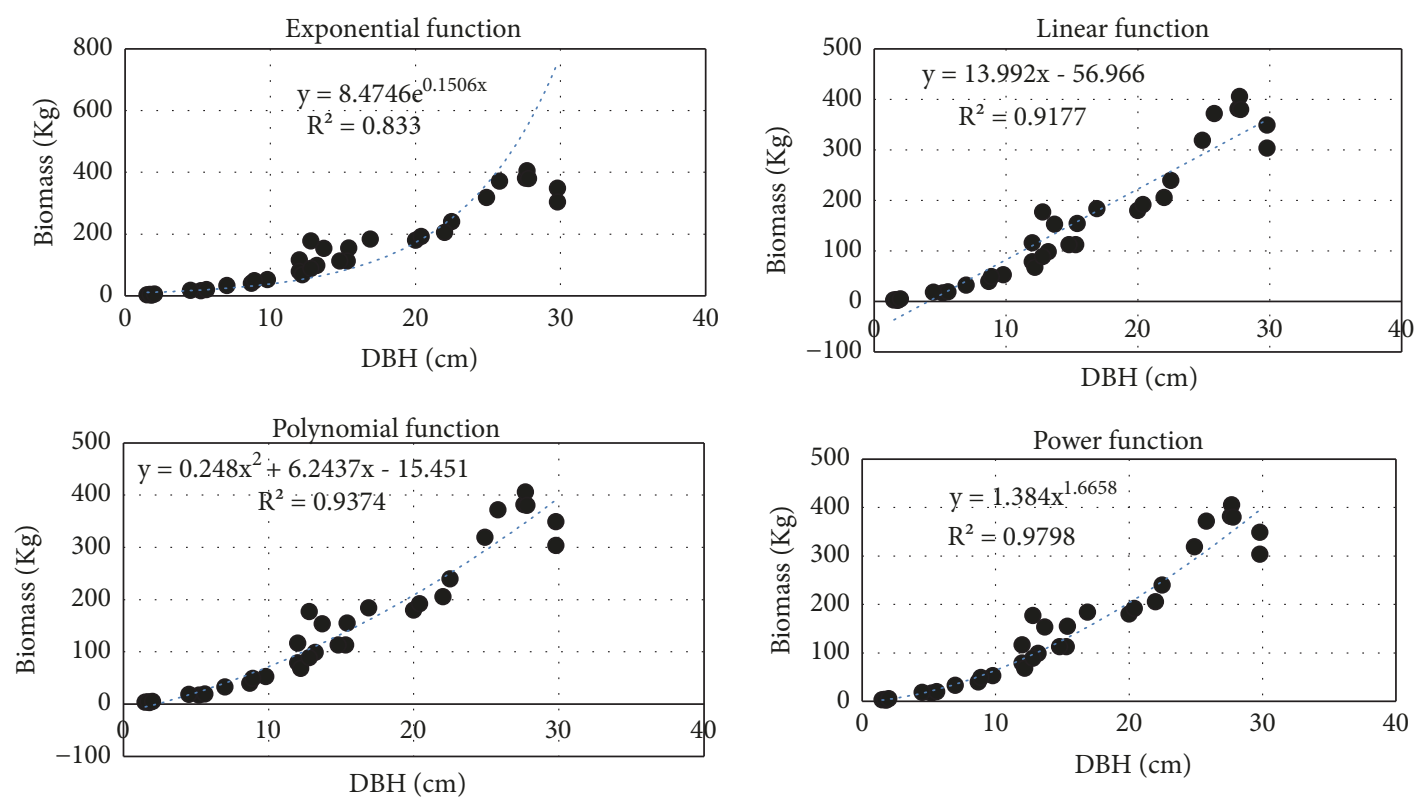

FIGURE 5: A comparison of functions for estimating above ground tree biomass from DBH.

TABLE 8: A validation of the equation with similar equations using the F values of the paired t-test.

\begin{tabular}{|c|c|c|c|c|}
\hline Author & F calculated & F critical & Comments & Discussion \\
\hline Kuya [5] & 1.5375557 & 1.8283 & $\begin{array}{l}\text { There is no } \\
\text { significant } \\
\text { difference }\end{array}$ & $\begin{array}{l}\text { The Kuya equation was developed in } \\
\text { similar Agroforestry conditions but in a } \\
\text { different AEZs of Kenya. }\end{array}$ \\
\hline Henry [1] & 0.817302 & 1.8283 & $\begin{array}{l}\text { There is no } \\
\text { significant } \\
\text { difference }\end{array}$ & $\begin{array}{l}\text { The equation was developed for } \\
\text { Agroforestry trees of Western Kenya in a } \\
\text { different AEZ. }\end{array}$ \\
\hline Benedicto [19] & 2.070408 & 1.8408 & $\begin{array}{l}\text { There is a } \\
\text { significant } \\
\text { difference. }\end{array}$ & $\begin{array}{c}\text { The equation was developed in Mexico. A } \\
\text { totally different biome and may not be } \\
\text { applicable in the study area. }\end{array}$ \\
\hline Rurangwa [18] & 1.118687 & 1.8408 & $\begin{array}{l}\text { There is no } \\
\text { significant } \\
\text { difference }\end{array}$ & $\begin{array}{l}\text { Rurangwa developed this equation in } \\
\text { Agroforestry trees of Ruanda which is } \\
\text { within East Africa. }\end{array}$ \\
\hline
\end{tabular}

TABLE 9: Average biomass values per hectare in AEZs.

\begin{tabular}{lcccc}
\hline \multirow{2}{*}{ Component } & \multicolumn{3}{c}{ Average biomass (Kg) per hectare } \\
& UM 1 & UM 2 & UM 3 & UM 4 \\
\hline Foliage & 922.128 & 874.343 & 724.966 & 788.837 \\
Branches/foliage & $1,964.818$ & $1,849.623$ & $1,533.623$ & \\
Roots/belowground biomass & $3,109.676$ & $2,927.150$ & $2,427.314$ & $1,668.739$ \\
Stem/trunk & $7,929.378$ & $7,457.484$ & $6,183.147$ & \\
\hline Total for tree & $13,926.00$ & $13,108.60$ & $10,869.05$ & $6,728.175$ \\
\hline
\end{tabular}

3.5. Validation of Developed Allometric Equations. Validation of the equations based on the bias of the equation in estimating specific diameter sizes is illustrated in residual plots used to assist in validation which are shown in Figure 6.

A second validation to compare biomass estimates from the preferred equation and that of similar studies shows that the developed equation compares well with other equations developed in agroforestry conditions of Kenya
$[1,5]$ and Rwanda [18] but is not applicable in biomes far from the study area [19]. This finding illustrates that the process of destructive sampling to develop new allometric equations within a small geographical range may not enhance accuracy of estimates and an equation applicable in a similar land and tree management activity may as well be applicable in another one. The results are illustrated in Table 8 . 

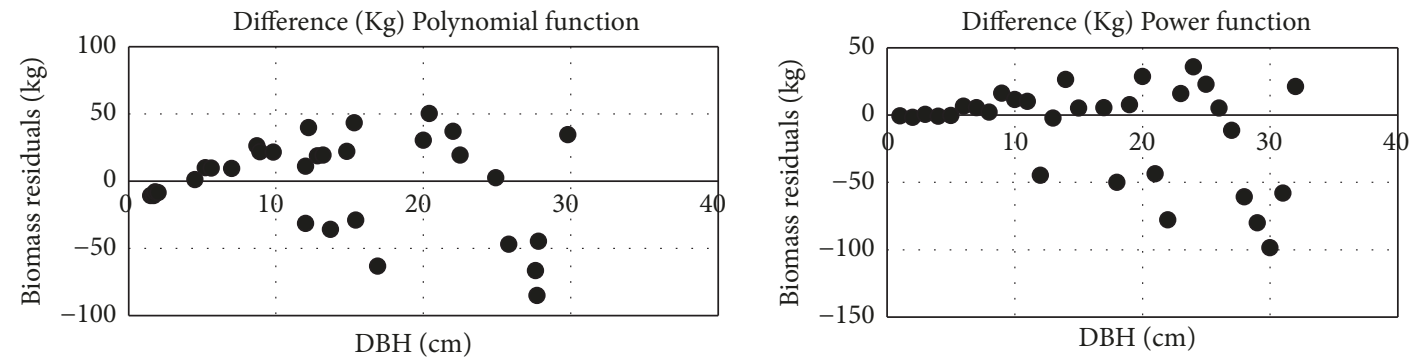

FIGURE 6: Residual scatter plots of total tree biomass using polynomial and power function for TTB.

TABLE 10: Total tree biomass and tree component biomass data of the 33 trees destructively sampled per every Agroecological Zone (AEZ).

\begin{tabular}{|c|c|c|c|c|c|c|c|c|c|}
\hline \multirow{2}{*}{ AEZ } & \multirow{2}{*}{ Tree No } & \multirow{2}{*}{$\mathrm{DBH}(\mathrm{cm})$} & \multirow{2}{*}{ Height (m) } & \multicolumn{6}{|c|}{ Dry weights of biomass in $\mathrm{kg}$} \\
\hline & & & & Stem & Branches & foliage & AGB & BGB & TTB \\
\hline \multirow{9}{*}{ UM4 } & 1 & 5.2 & 6.55 & 10.16 & 1.625 & 5.22 & 17.01 & 3.82 & 20.83 \\
\hline & 2 & 1.5 & 3.6 & 1.55 & 0.644 & 1.02 & 3.31 & 0.801 & 4.01 \\
\hline & 3 & 12 & 14.3 & 93.69 & 10.62 & 12.1 & 116.41 & 37.43 & 153.84 \\
\hline & 4 & 13.2 & 12.7 & 70.22 & 11.08 & 17.49 & 98.79 & 23.46 & 122.25 \\
\hline & 5 & 22.5 & 16.7 & 166.66 & 50.3 & 22.92 & 239.88 & 63.14 & 303.02 \\
\hline & 6 & 29.8 & 14.5 & 247.52 & 80.42 & 21.27 & 349.21 & 119.55 & 468.76 \\
\hline & $7 \mathrm{~V}$ & 1.8 & 6.0 & 1.65 & 0.33 & 0.662 & 2.64 & 1.461 & 4.10 \\
\hline & $8 \mathrm{~V}$ & 13.7 & 14.5 & 112.22 & 26.61 & 14.64 & 153.47 & 32.42 & 185.89 \\
\hline & $9 \mathrm{~V}$ & 20 & 16.1 & 134.87 & 31.5 & 13.75 & 180.12 & 57.79 & 237.91 \\
\hline \multirow{9}{*}{ UM3 } & 10 & 12.0 & 12.75 & 59.01 & 6.88 & 13.14 & 79.03 & 32.4 & 111.43 \\
\hline & 11 & 15.4 & 13.7 & 109.4 & 24.75 & 20.65 & 154.8 & 53.63 & 208.43 \\
\hline & 12 & 7.0 & 8.65 & 20.38 & 5.0 & 7.5 & 32.88 & 9.83 & 42.71 \\
\hline & 13 & 5.6 & 8.65 & 12.68 & 2.8 & 4.13 & 19.61 & 5.94 & 25.55 \\
\hline & 14 & 27.6 & 19.0 & 270.53 & 92.98 & 17.97 & 381.48 & 130.37 & 511.85 \\
\hline & 15 & 27.7 & 19.2 & 306.55 & 83.25 & 16.0 & 405.8 & 127.08 & 532.88 \\
\hline & $16 \mathrm{~V}$ & 16.9 & 12.2 & 118.03 & 43.65 & 22.39 & 184.07 & 86.03 & 270.1 \\
\hline & $17 \mathrm{~V}$ & 9.8 & 9.1 & 32.69 & 10.0 & 10.2 & 52.89 & 15.01 & 67.94 \\
\hline & $18 \mathrm{~V}$ & 25.8 & 16.6 & 275.16 & 63.58 & 33.26 & 372.0 & 74.95 & 446.95 \\
\hline \multirow{9}{*}{ UM2 } & 19 & 1.7 & 7.1 & 1.95 & 0.6 & 1.45 & 4.0 & 1.79 & 5.79 \\
\hline & 20 & 8.7 & 9.8 & 24.98 & 6.43 & 8.75 & 40.16 & 7.86 & 48.02 \\
\hline & 21 & 15.3 & 14.3 & 58.83 & 38.5 & 15.51 & 112.84 & 21.46 & 134.30 \\
\hline & 22 & 14.8 & 15.0 & 69.63 & 32.71 & 10.46 & 112.8 & 33.99 & 146.79 \\
\hline & $23 \mathrm{~V}$ & 12.2 & 12.4 & 40.63 & 13.93 & 13.5 & 68.06 & 17.75 & 85.81 \\
\hline & $24 \mathrm{~V}$ & 12.8 & 15.4 & 62.94 & 19.15 & 7.0 & 89.09 & 27.26 & 116.35 \\
\hline & 25 & 22.0 & 17.0 & 164.71 & 30.03 & 11.09 & 205.83 & 68.36 & 274.19 \\
\hline & 26 & 29.8 & 21.2 & 259.8 & 33.2 & 10.89 & 303.89 & 79.34 & 383.23 \\
\hline & $27 \mathrm{~V}$ & 27.8 & 24.8 & 327.63 & 43.9 & 8.71 & 380.24 & 114.75 & 494.99 \\
\hline \multirow{6}{*}{ UM1 } & 28 & 2.0 & 6.0 & 3.21 & 0.94 & 1.19 & 5.34 & 1.01 & 6.35 \\
\hline & 29 & 8.9 & 9.9 & 28.87 & 10.25 & 10.01 & 49.13 & 5.90 & 55.03 \\
\hline & $30 \mathrm{~V}$ & 4.5 & 9.1 & 11.96 & 2.5 & 3.86 & 18.32 & 3.60 & 21.92 \\
\hline & 31 & 12.8 & 13.0 & 114.66 & 31.50 & 31.22 & 177.38 & 65.22 & 242.6 \\
\hline & 32 & 24.9 & 19.0 & 262.84 & 37.75 & 18.57 & 319.16 & 56.50 & 375.66 \\
\hline & 33 & 20.4 & 11.5 & 128.71 & 46.9 & 16.2 & 191.81 & 34.60 & 226.41 \\
\hline
\end{tabular}


TABLE 11: Allometric equations for estimating branch biomass using DBH.

\begin{tabular}{|c|c|c|c|c|}
\hline Function & Equation & MRE & $\mathrm{R}^{2}$ & SEE \\
\hline Exponential & $B R=4.644 e^{0.069 D b h}$ & 11.72 & 0.93 & 0.75 \\
\hline Logarithmic & $B R=10.56 \ln (D B H)+1.534$ & 0.02 & 0.84 & 0.72 \\
\hline Polynomial & $B R=0.077 D B H^{2}+3.373 D B H+0.213$ & -4.53 & 0.99 & 0.58 \\
\hline Linear & $B R=0.941 D B H+13.24$ & 0.03 & 0.96 & 0.73 \\
\hline Power & $B R=1.901 D B H^{0.793}$ & 11.59 & 0.99 & $0.73 \mathrm{~s}$ \\
\hline
\end{tabular}

TABLE 12: Allometric equations for estimating foliage using DBH.

\begin{tabular}{|c|c|c|c|c|}
\hline Function & Equation & MRE & $\mathrm{R}^{2}$ & SEE \\
\hline Exponential & $F=4.795 e^{0.045 D B H}$ & 2.74 & 0.97 & 0.24 \\
\hline Logarithmic & $F=3.62 \ln (D B H)+4.020$ & 0.02 & 0.84 & 0.22 \\
\hline Polynomial & $F=-0.031 D B H^{2}+1.270 D B H+3.235$ & -1.83 & 0.99 & 0.58 \\
\hline Linear & $F=0.295 D B H+8.452$ & 0.003 & 0.97 & 0.23 \\
\hline Power & $F=2.213 D B H^{0.596}$ & -2.37 & 0.98 & 0.23 \\
\hline
\end{tabular}

TABLE 13: Allometric equations for estimating TTB using HT.

\begin{tabular}{|c|c|c|c|c|}
\hline Function & Equation & MRE & $\mathrm{R}^{2}$ & SEE \\
\hline Exponential & $T T B=3.090 e^{0.266 H T}$ & -37.50 & 0.54 & 10.10 \\
\hline Logarithmic & $T T B=315.7 \ln (H T)-597.3$ & 0.06 & 0.93 & 3.00 \\
\hline Polynomial & $T T B=-0.0409 H T^{2}+18.63 H T+132.7$ & 0.21 & 0.99 & 2.52 \\
\hline Linear & $T T B=29.69 H T-198.0$ & 0.02 & 0,74 & 2.55 \\
\hline Power & $T T B=0.401 H T^{.1 .642}$ & -5.44 & 0.97 & 0.53 \\
\hline
\end{tabular}

TABLE 14: Allometric equations for estimating AGB using HT.

\begin{tabular}{|c|c|c|c|c|}
\hline Function & Equation & MRE & $\mathrm{R}^{2}$ & SEE \\
\hline Exponential & $A G B=2.454 e^{0.263 H T}$ & -24.37 & 0.54 & 7.44 \\
\hline Logarithmic & $A G B=240.1 \ln (H)-452.6$ & 0.084 & 0.93 & 2.48 \\
\hline Polynomial & $A G B=-0.312 H T^{2}+14.11 H T-98.72$ & 0.24 & 0.99 & 2.10 \\
\hline Linear & $A G B=22.55 H T-148.50$ & 0.02 & 0.70 & 2.12 \\
\hline Power & $A G B=0.027 H T^{3.174}$ & 7.93 & 0.82 & 2.86 \\
\hline
\end{tabular}

TABLE 15: Allometric equations for estimating BGB using HT.

\begin{tabular}{|c|c|c|c|c|}
\hline Function & Equation & MRE & $\mathrm{R}^{2}$ & SEE \\
\hline Exponential & $B G B=0.631 e^{0.269 H T}$ & -6.22 & 0.53 & 2.26 \\
\hline Logarithmic & $B G B=70.7 \ln (H T)-133.3$ & -0.04 & 0.93 & 0.79 \\
\hline Polynomial & $B G B=-0.067 H T^{2}+4.781 H T-32.58$ & 0.15 & 1 & 0.71 \\
\hline Linear & $B G B=6.009 H T-43.45$ & 0.10 & 0.64 & 23.52 \\
\hline Power & $B G B=0.006 H T^{3.241}$ & 5.84 & 0.80 & 31.34 \\
\hline
\end{tabular}

TABLE 16: Allometric equations for estimating TTB using combination of DBH and HT $(\mathrm{DBH} * \mathrm{HT}=\mathrm{P})$.

\begin{tabular}{|c|c|c|c|c|}
\hline Function & Equation & MRE & $\mathrm{R}^{2}$ & SEE \\
\hline Exponential & $T T B=23.48 e^{0.006 P}$ & -7.61 & 0.73 & 6.67 \\
\hline Logarithmic & $T T B=107.7 \ln (P)-339.7$ & 0.002 & 0.72 & 2.85 \\
\hline Polynomial & $T T B=-0.000 P^{2}+1.11 P-2.05$ & -4.02 & $I$ & 2.52 \\
\hline Linear & $T T B=0.829 P-0.929$ & 0.06 & 0.90 & 1.58 \\
\hline Power & $T T B=0.395 P^{1.125}$ & 2.15 & 0.98 & 2,68 \\
\hline
\end{tabular}


TABLE 17: Allometric equations for estimating AGB using combination of $\mathrm{DBH}$ and $\mathrm{HT}(\mathrm{DBH} * \mathrm{HT}=\mathrm{P})$.

\begin{tabular}{|c|c|c|c|c|}
\hline Function & Equation & MRE & $\mathrm{R}^{2}$ & SEE \\
\hline Exponential & $A G B=18.26 e^{0.0006 P}$ & -7.46 & 0.73 & 5.24 \\
\hline Logarithmic & $A G B=82.22 \ln (P)-258.1$ & -6.88 & 0.72 & 2.31 \\
\hline Polynomial & $A G B=-0.000 P^{2}+0.829 P-16.09$ & -2.9 & 1 & 1.85 \\
\hline Linear & $A G B=0.630 P+0.965$ & 0.19 & 0.86 & 1.46 \\
\hline Power & $A G B=0.310 P^{1.119}$ & 3.837 & 0.99 & 1.52 \\
\hline
\end{tabular}

TABLE 18: Allometric equations for estimating BGB using combination of DBH and $\mathrm{HT}(\mathrm{DBH} * \mathrm{HT}=\mathrm{P})$.

\begin{tabular}{|c|c|c|c|c|}
\hline Function & Equation & MRE & $\mathrm{R}^{2}$ & SEE \\
\hline Exponential & $B G B=4.95 e^{0.0006 P}$ & 1.34 & 0.73 & -1.45 \\
\hline Logarithmic & $B G B=24.24 \ln (P)-76.22$ & 0.01 & 0.72 & 0.75 \\
\hline Polynomial & $B G B=-0.000 P^{2}+0.255 P-5.495$ & -1.01 & 1 & 0.69 \\
\hline Linear & $B G B=0.184 P+0.575$ & 0.07 & 0.78 & 0.75 \\
\hline Power & $B G B=0.084 P^{1.125}$ & 3.06 & 0.99 & 0.75 \\
\hline
\end{tabular}

TABLE 19: Generated TTB from developed equation using DBH.

\begin{tabular}{|c|c|c|c|c|c|c|c|}
\hline UM 1 & GEN & UM 2 & GEN. & UM 3 & GEN & UM 4 & GEN \\
\hline $\mathrm{DBH}$ & $\mathrm{BIOM}$ & $\mathrm{DBH}$ & $\mathrm{BIOM}$ & $\mathrm{DBH}$ & $\mathrm{BIOM}$ & $\mathrm{DBH}$ & BIOM \\
\hline 12.8 & 129.5594 & 13.9 & 147.4242 & 18.6 & 233.6786 & 30.3 & 518.2414 \\
\hline 2.4 & 4.18944 & 1 & 6.674 & 17 & 202.51 & 29.8 & 504.0422 \\
\hline 1 & 6.674 & 9.2 & 77.25136 & 9.1 & 75.93304 & 1 & 6.674 \\
\hline 1 & 6.674 & 1 & 6.674 & 18.8 & 237.7058 & 4.4 & 22.18384 \\
\hline 4.4 & 22.18384 & 1 & 6.674 & 14.6 & 159.2514 & 26.5 & 414.892 \\
\hline 15.4 & 173.205 & 13.5 & 140.826 & 18.5 & 231.676 & 1 & 6.674 \\
\hline 16 & 183.976 & 1 & 6.674 & 2.5 & 5.02 & 1 & 6.674 \\
\hline 10 & 88.06 & 16 & 183.976 & 16 & 183.976 & 1 & 6.674 \\
\hline 10 & 88.06 & 3 & 9.282 & 19.4 & 249.9618 & 16 & 183.976 \\
\hline 13 & 132.742 & 15.4 & 173.205 & 10.8 & 99.33456 & 18 & 221.772 \\
\hline 12.8 & 129.5594 & 21.5 & 294.922 & 15.3 & 171.4354 & 13.5 & 140.826 \\
\hline 20.9 & 281.7486 & 1.7 & 1.42064 & 12.8 & 129.5594 & 1 & 6.674 \\
\hline 2.2 & 2.55016 & 12.2 & 120.1862 & 16.2 & 187.6246 & 14.8 & 162.6962 \\
\hline 19 & 241.762 & 8 & 61.912 & 20.9 & 281.7486 & 17.5 & 212.05 \\
\hline 2 & 0.94 & 8.76 & 71.50521 & 19 & 241.762 & 16 & 183.976 \\
\hline 8.9 & 73.31824 & 13 & 132.742 & 2.2 & 2.55016 & 15 & 166.17 \\
\hline 1.4 & 3.71576 & 1 & 6.674 & 7.8 & 59.45736 & 18.5 & 231.676 \\
\hline 1.2 & 5.20944 & 1 & 6.674 & 5.2 & 30.19696 & 14 & 149.092 \\
\hline 16.5 & 193.152 & 1 & 6.674 & 4.5 & 23.16 & 16.5 & 193.152 \\
\hline 12.6 & 126.4058 & 1.5 & 2.958 & 4.5 & 23.16 & 12.6 & 126.4058 \\
\hline 15.3 & 171.4354 & 1 & 6.674 & 2.4 & 4.18944 & 15.3 & 171.4354 \\
\hline 13 & 132.742 & 2 & 0.94 & 4.2 & 20.25336 & 1 & 6.674 \\
\hline 11.8 & 114.083 & 9.7 & 83.95216 & 5.1 & 29.16984 & 13 & 132.742 \\
\hline 1.4 & 3.71576 & 9.6 & 82.59744 & 2.5 & 5.02 & 11.8 & 114.083 \\
\hline 3.3 & 11.92656 & 12.2 & 120.1862 & 4.5 & 23.16 & 14.5 & 157.54 \\
\hline 1.5 & 2.958 & 8.7 & 70.73256 & 5.4 & 32.27304 & 17.1 & 204.4034 \\
\hline 2 & 0.94 & 8.3 & 65.64856 & 2.6 & 5.85784 & 1 & 6.674 \\
\hline 1 & 6.674 & 10.9 & 100.7766 & 1 & 6.674 & 1 & 6.674 \\
\hline 17.1 & 204.4034 & 6.8 & 47.62096 & 1 & 6.674 & 18 & 221.772 \\
\hline 17.1 & 204.4034 & 6.9 & 48.77184 & 9 & 74.622 & 1 & 6.674 \\
\hline
\end{tabular}


TABLE 19: Continued.

\begin{tabular}{|c|c|c|c|c|c|c|c|}
\hline UM 1 & GEN & UM 2 & GEN. & UM 3 & GEN & UM 4 & GEN \\
\hline $\mathrm{DBH}$ & BIOM & $\mathrm{DBH}$ & BIOM & $\mathrm{DBH}$ & $\mathrm{BIOM}$ & $\mathrm{DBH}$ & $\mathrm{BIOM}$ \\
\hline 9 & 74.622 & 2.9 & 8.41504 & 10.5 & 95.052 & 12.4 & 123.2814 \\
\hline 11.4 & 108.0962 & 1 & 6.674 & 4.6 & 24.14344 & 11.4 & 108.0962 \\
\hline 10.8 & 99.33456 & 5.1 & 29.16984 & 1 & 6.674 & 10.8 & 99.33456 \\
\hline 11 & 102.226 & 11 & 102.226 & 1 & 6.674 & 9.3 & 78.57696 \\
\hline 10.5 & 95.052 & 1 & 6.674 & 1 & 6.674 & 11.8 & 114.083 \\
\hline 12 & 117.12 & 12 & 117.12 & 1 & 6.674 & 15.6 & 176.7662 \\
\hline 7 & 49.93 & 10.4 & 93.63904 & 1 & 6.674 & 7 & 49.93 \\
\hline 12.2 & 120.1862 & 5.2 & 30.19696 & 7 & 49.93 & 17.5 & 212.05 \\
\hline 11.1 & 103.6826 & 11.1 & 103.6826 & 5.3 & 31.23136 & 14.4 & 155.8358 \\
\hline 13 & 132.742 & 6.1 & 39.76864 & 1.3 & 4.46624 & 11.8 & 114.083 \\
\hline 10 & 88.06 & 1 & 6.674 & 1.8 & 0.64104 & 10 & 88.06 \\
\hline 12.8 & 129.5594 & 12.8 & 129.5594 & 1 & 6.674 & 13 & 132.742 \\
\hline 20 & 262.48 & 6.8 & 47.62096 & 1 & 6.674 & 8 & 61.912 \\
\hline 1 & 6.674 & 1 & 6.674 & 1 & 6.674 & 13.8 & 145.7638 \\
\hline 10.4 & 93.63904 & 1 & 6.674 & 1 & 6.674 & 11.4 & 108.0962 \\
\hline 14 & 149.092 & 1 & 6.674 & 9.8 & 85.31416 & 15.4 & 173.205 \\
\hline 16 & 183.976 & 10.4 & 93.63904 & 1 & 6.674 & 8.4 & 66.90864 \\
\hline 19.5 & 252.03 & 6.2 & 40.86856 & 1 & 6.674 & 7.8 & 59.45736 \\
\hline 8.1 & 63.15024 & 9.5 & 81.25 & 2.8 & 7.55536 & 22.5 & 317.46 \\
\hline 5.6 & 34.37824 & 8.5 & 68.176 & 4.9 & 27.13744 & 1 & 6.674 \\
\hline 5.2 & 30.19696 & 6.5 & 44.212 & 4.2 & 20.25336 & 15.6 & 176.7662 \\
\hline 10 & 88.06 & 8.1 & 63.15024 & 12.1 & 118.6494 & 1 & 6.674 \\
\hline 13 & 132.742 & 1 & 6.674 & 8.7 & 70.73256 & 1 & 6.674 \\
\hline 16.9 & 200.6238 & 1 & 6.674 & 5.6 & 34.37824 & 2.9 & 8.41504 \\
\hline 21 & 283.926 & 8.2 & 64.39576 & 1 & 6.674 & 13.6 & 142.4646 \\
\hline 21 & 283.926 & 5.7 & 35.44176 & 15 & 166.17 & 16.4 & 191.3022 \\
\hline 13 & 132.742 & 1 & 6.674 & 20.2 & 266.711 & 1 & 6.674 \\
\hline 3.9 & 17.41224 & 6 & 38.676 & 29.7 & 501.2242 & 1 & 6.674 \\
\hline 17.3 & 208.2122 & 1 & 6.674 & 19.5 & 252.03 & 17 & 202.51 \\
\hline 16 & 183.976 & 1 & 6.674 & 23 & 329.002 & 16 & 183.976 \\
\hline 16 & 183.976 & 1 & 6.674 & 2.3 & 3.36616 & 18.7 & 235.6886 \\
\hline 21 & 283.926 & 6.4 & 43.09024 & 18.3 & 227.6926 & 10.4 & 93.63904 \\
\hline 18.7 & 235.6886 & 4.8 & 26.13216 & 12 & 117.12 & 12.2 & 120.1862 \\
\hline 3.9 & 17.41224 & 1 & 6.674 & 5.4 & 32.27304 & 13 & 132.742 \\
\hline 13.2 & 135.9538 & 1 & 6.674 & 13.2 & 135.9538 & 18 & 221.772 \\
\hline 18 & 221.772 & 1 & 6.674 & 2 & 0.94 & 1 & 6.674 \\
\hline 5.8 & 36.51256 & 1.5 & 2.958 & 1 & 6.674 & 1 & 6.674 \\
\hline
\end{tabular}

3.6. Biomass Stocks among Agroecological Zones. Based on the allometric equations, the average TTB for G. robusta trees generated in each of the AEZ studied is as shown in Table 9. The TTB stock for each AEZ was 13. 926 tonha $^{-1}, 13.109$ tonha $^{-1}, 10.869$ tonha $^{-1}$, and 11.827 tonha $^{-1}$ in UM1, UM2, UM3, and UM4, respectively. Variability of tree biomass between the four agroecological zones showed no significant difference ( $\mathrm{p}$-value $>0.05$ ) implying that though there could be a slight difference in the allometry of the tree species among AEZ, the total biomass does not vary. This also explains that the management of $G$ robusta trees in the agricultural landscapes of the four AEZ does not differ and the farmers can form a marketing unit despite their different AEZ and their production quotas can be the same.

The average biomass stock of 12.43 ton/ha in the study compares well with the findings of Albrecht [20], 2-22 ton/ha, Henry [1], 9-11ton/ha, and Kuya [5], 16 ton/ha, all of which are for agricultural landscapes. This finding gives a better glimpse of the tree component in agricultural landscapes and is a good guide for the development of carbon stock factors in agricultural landscapes [21]. With this moderate stock, the farmers are able to 
practice agricultural activities while maintaining a tree cover in the farms which stabilizes the agricultural landscapes and reduces pressure for wood products from adjacent forests.

\section{Conclusion and Recommendations}

This study has developed a quick tool for estimating biomass from G. robusta trees in agricultural landscapes of Maragua county. The allometric equations allow better marketing of the trees and their components and will favor farmers who will get better value from their trees. The findings illustrate no much variations in stocking among the study strata and also comparing with studies in similar agricultural setups. Therefore the study illustrates the usability of general allometric equations which eliminate the expensive processes of destructive sampling. As such the developed equations are ideal for a wide range of application in areas of Kenya where $G$. robusta grows without any need to develop other equations.

The study identified only small sized G. robusta trees and the size limitation is influenced by their growth characteristics and the market conditions. The study proposes a validation of the allometric equations in cases where bigger sized trees exist. Similarly the small sample size used in this study may have not captured enough information on the allometry of the tree and a collation of this data and other existing datasets can help compare characteristics of allometry that may influence the equation used

\section{Appendix}

A.

See Table 10.

B.

See Tables 11, 12, 13, 14, 15, 16, 17, and 18 .

C.

See Table 19.

\section{Data Availability}

The data used to support the findings of this study are available from the corresponding author upon request.

\section{Disclosure}

The research was done as a part of a Master's thesis and was financed by the first author.

\section{Conflicts of Interest}

The authors have no conflicts of interest in the manuscripts and therefore do declare that there are no conflicts of interest regarding the publication of this paper.

\section{Acknowledgments}

The authors wish to acknowledge the Department of Natural Resources in Karatina University where the student is registered for providing supervision and guidelines. The authors would also like to thank Kenya Forest Service (KFS) authorities for giving a permission to conduct the study using their staff members and the farmers who allowed uprooting of trees in their farms.

\section{References}

[1] M. Henry, P. Tittonell, and R. J. Manlay, "Biodiversity, carbon stocks and sequestration potential in abovegroundbiomass in Smallholderfarming systems ofwestern Kenya," Agriculture, Ecosystems and Environment, vol. 129, no. 1, pp. 238-252, 2009.

[2] K. P. Acharya, "Linking trees on farms with biodiversity conservation in subsistence farming systems in Nepal," Biodiversity and Conservation, vol. 15, no. 2, pp. 631-646, 2006.

[3] P. Daniel and K. Michael, "Estimating carbon emissions from forest degradation: implications of uncertainties and area sizes for a REDD+ MRV system," Canadian Journal of Forest Resources, vol. 42, Article ID 19962010, pp. 1996-2010, 2012.

[4] B. Verbist, M. Vangoidsenhoven, R. Dewulf, and B. Muys, Reducing Emissions from Deforestation and Degradation (REDD), KLIMOS, Leuven, Belgium, 2011.

[5] S. Kuyah, J. Dietz, and C. Muthuri, "Allometric equations for estimating biomass in agricultural landscapes: II Belowgroundbiomass," Agriculture, Ecosystems and Environment, vol. 158, pp. 225-234, 2012.

[6] M. J. Kinyanjui, P. Latva-Käyrä, P. S. Bhuwneshwar, P. Kariuki, A. Gichu, and K. Wamichwe, "An inventory of the above ground biomass in the mau forest ecosystem, Kenya," Open Journal of Ecology, vol. 04, no. 10, pp. 619-627, 2014.

[7] J. M. Mugo, J. T. Njunge, and R. E. Malimbwi, "Models for predicting stem diameter from crown diameter of open grown trees in sondu- nyando river catchment," Asian Journal of Agricultural Sciences, vol. 15, pp. 119-126, 2011.

[8] M. Henry, N. Picard, C. Trotta et al., "Estimating tree biomass of sub-Saharan African forests: A review of available allometric equations," Silva Fennica, vol. 45, no. 3, pp. 477-569, 2011.

[9] R. Mesquita, J. L. Pereira, and De Souza, State of the environment Maragua District, NEMA (National Environmental Management Authority), Nairobi, Kenya, 2004.

[10] R. Jaetzold, H. Schmidt, B. Hormetz, and C. Shisanya, "Natural Conditions and Farm Management Information," in Farm Management Handbook of Kenya, Ministry of Agriculture, Nairobi, Kenya, 2nd edition, 2006.

[11] J. K. Githiomi and D. N. Mugendi, "Household tree planting and its relatedconstraints in meeting woodfuel production in Kiambu, Thika and Maragwa Districts of Central Kenya," Journal of Horticulture and Forestry, vol. 4, no. 7, pp. 120-125, 2012.

[12] S. S. Chauhan and J. C. F. Walker, "Variations in acoustic velocity and density with age, and their interrelationships in radiata 
pine," Forest Ecology and Management, vol. 229, no. 1-3, pp. 388394, 2006.

[13] J. Chave, C. Andalo, S. Brown et al., "Tree allometry and improved estimation of carbon stocks and balance in tropical forests," Oecologia, vol. 145, no. 1, pp. 87-99, 2005.

[14] J. H. Zar, Biostatistical Analysis, Prentice Hall, Upper Saddle River, 4th edition, 1999.

[15] J. Glenday, "Carbon storage and emissions offset potential in an East African tropical rainforest," Forest Ecology and Management, vol. 235, no. 1-3, pp. 72-83, 2006.

[16] J. Pastor, J. D. Aber, and J. M. Melillo, "Biomass prediction using generalized allometric regressions for some northeast tree species," Forest Ecology and Management, vol. 7, no. 4, pp. 265274, 1984.

[17] E. T. Mitchard, S. S. Saatchi, L. J. White et al., "Mapping tropical forest biomass with radar and spaceborne LiDAR in Lopé National Park, Gabon: overcoming problems of high biomass and persistent cloud," Biogeosciences, vol. 9, no. 1, pp. 179-191, 2012.

[18] F. Rurangwa, M. J. Kinyanjui, F. Bazimaziki et al., "Developing a Forest Management Plan (DFMP) for gatsibo district in the eastern province of Rwanda," Open Journal of Forestry, vol. 8, pp. 247-265, 2018.

[19] V-L. Benedicto, A. Carlos L, J. José, OL-M. Jorge, G. A. C. Cristóbal, and G. Á. Juan, "Allometric equations for estimating biomass and carbon stocks in the temperate forests of NorthWestern Mexico," Forests, vol. 8, no. 269, 2017.

[20] A. Albrecht and S. T. Kandji, "Carbon sequestration in tropical agroforestry systems," Agriculture, Ecosystems and Environment, vol. 99, no. 1, pp. 15-27, 2003.

[21] IPCC, Guidelines for National Greenhouse Gas Inventories, vol. 4 of Agriculture, Forestry and Other Land Use, The Intergovernmental Panel on Climate Change, 2006, http://www.ipcc-nggip.iges.or.jp/public/2006gl/pdf/4

Volume4/V4_04_Ch4_Forest_Land. 

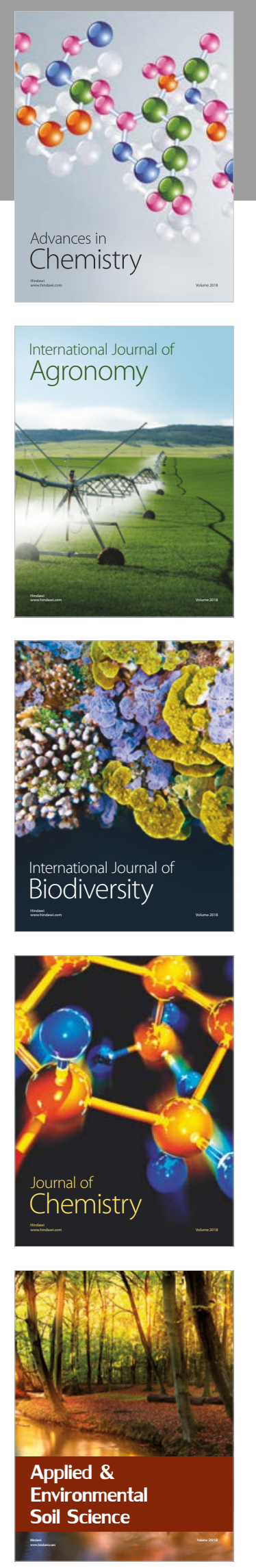

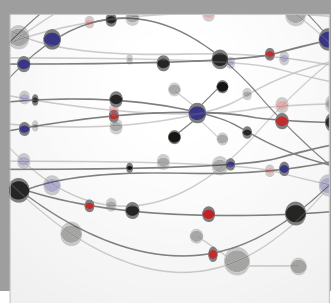

The Scientific World Journal

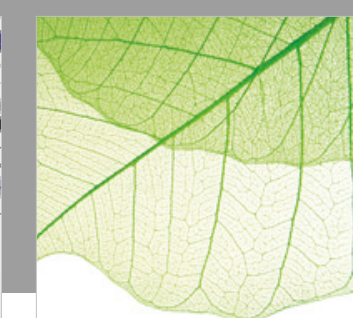

Journal of Botany

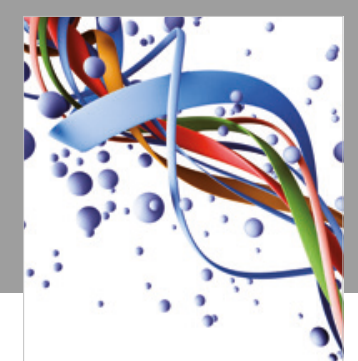

Scientifica

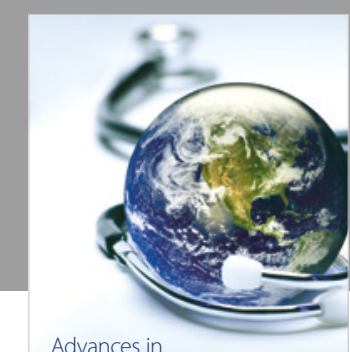

Public Health

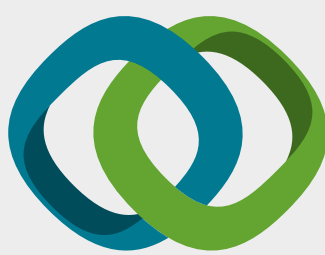

Hindawi

Submit your manuscripts at

www.hindawi.com
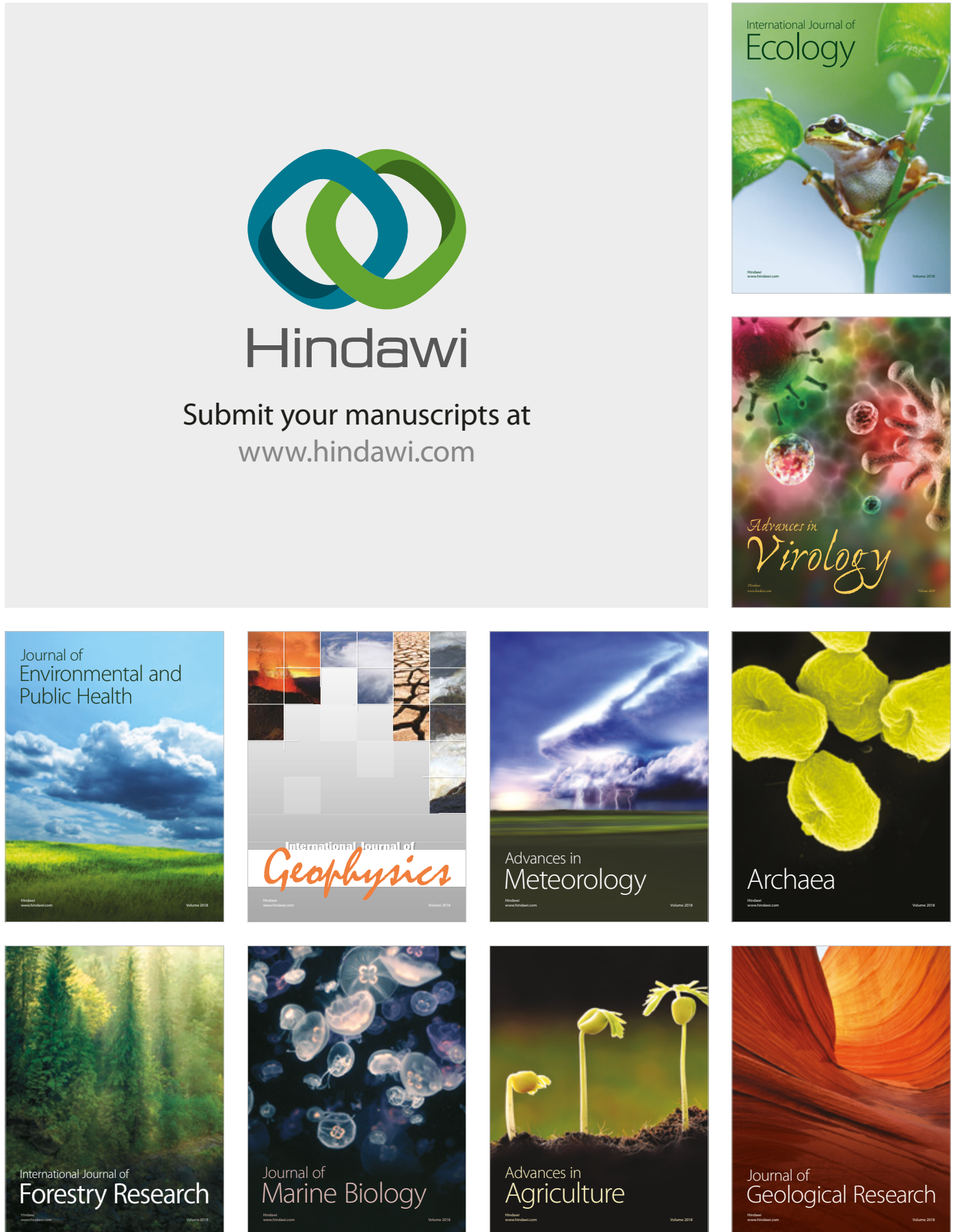

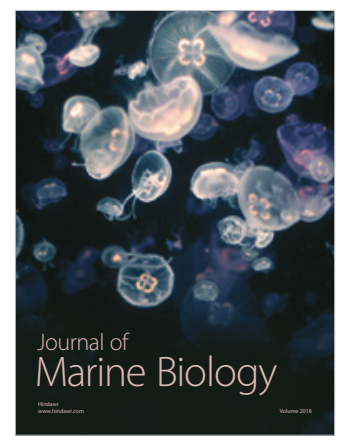

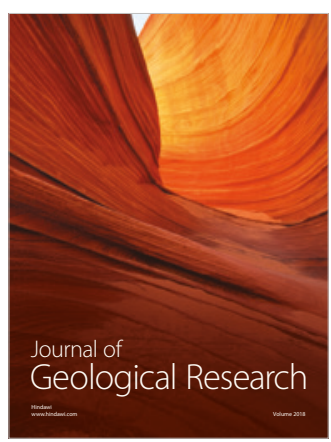

